\begin{tabular}{|c|c|}
\hline $\begin{array}{l}\text { Chemistry of } \\
\text { Metals and Allovs }\end{array}$ & 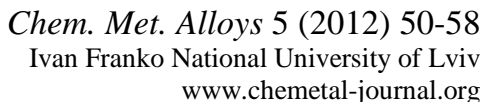 \\
\hline
\end{tabular}

\title{
Crystallization of $\mathrm{Al}_{87} \mathrm{Y}_{5} \mathrm{Ni}_{8}$ amorphous alloys doped with $\mathrm{Dy}$ and $\mathrm{Fe}$
}

\author{
Taras MIKA ${ }^{1 *}$, Malgorzata KAROLUS ${ }^{2}$, Lidiya BOICHYSHYN ${ }^{1}$, Grzegorz HANECZOK ${ }^{2}$, Bohdan KOTUR ${ }^{1}$, \\ Viktor NOSENKO ${ }^{3}$ \\ ${ }^{1}$ Faculty of Chemistry, Ivan Franko National University of Lviv, Kyryla i Mefodiya St. 6, 79005 Lviv, Ukraine \\ ${ }^{2}$ Institute of Material Science, University of Silesia, Bankowa 12, 40-007 Katowice, Poland \\ ${ }^{3}$ Kurdyumov Institute for Physics of Metals, NAS of Ukraine, Vernadsky Ave. 36, 03680 Kyiv, Ukraine \\ * Corresponding author. E-mail: mikat@ukr.net
}

Received April 17, 2012; accepted June 27, 2012; available on-line November 5, 2012

Amorphous alloys have been investigated by applying differential scanning calorimetry (DSC), X-ray diffraction (XRD) and high resolution electron microscopy (HREM). Replacement of $Y$ by Dy shifts the primary crystallization to lower temperatures, substitution of $\mathrm{Fe}$ for $\mathrm{Ni}$ shifts the nanocrystallization to higher temperatures. The $R E$ elements play a dominant role at the first stage of crystallization, the $T M$ elements take part in the crystallization only at the final stage. For alloys with Dy the first two stages of crystallization are attributed to the formation of fec $\mathrm{Al}(R E)$. At the third stage of crystallization, precipitation of the ternary compound $R E_{3} \mathrm{Ni}_{5} \mathrm{Al}_{19}$ with an orthorhombic $\mathrm{Gd}_{3} \mathrm{Ni}_{5} \mathrm{Al}_{19}$-type structure was observed. The interaction between $\mathrm{Dy}$ and $\mathrm{Fe}$ atoms completely changes the crystallization path of the $\mathrm{Al}_{87} \mathrm{Dy}_{5} \mathrm{Ni}_{4} \mathrm{Fe}_{4}$ alloy, i.e. primary crystallization is attributed to precipitation of unidentified intermetallic compounds and the following stages to the formation of intermetallics isotypic with $\mathrm{CeMn}_{4} \mathrm{Al}_{8}$ and $\mathrm{YbFe}_{2} \mathrm{Al}_{10}$.

X-ray diffraction / Aluminium alloys / Amorphous alloys / Nanostructured materials / Phase transformation

\section{Introduction}

Amorphous metallic alloys (AMA), and especially $\mathrm{Al}-R E-T M(R E=$ rare-earth metal, $T M=$ transition metal) Al-based alloys, attract interest because of their remarkable properties, such as good ductility and corrosion resistance [1,2]. It is a well-known fact that nanocrystallization can improve the corrosion resistance and mechanical properties of Al-based AMAs. Understanding the processes of primary crystallization helps controlling the nanocrystallization and may, consequently, improve the properties. The alloys of the Al-Y-Ni ternary system have relatively broad ranges of existence of the amorphous state in comparison with other $\mathrm{Al}-R E-T M$ systems [1]. That is why the investigation of this system is attractive for doping its alloys with other elements in a broad range and evaluating the influence on the thermal stability and other characteristics.

There is a large amount of data in the literature on the crystallization of $\mathrm{Al}-R E-T M$ amorphous alloys. The $\mathrm{Al}_{85} \mathrm{Y}_{\mathrm{x}} \mathrm{Ni}_{15-\mathrm{x}}(\mathrm{x}=5,7,8,10)$ AMAs undergo three stages of crystallization for the alloys with $\mathrm{x}=5,7$ and four stages for $\mathrm{x}=8,10$ [3]. For the alloys with $\mathrm{x}=5,7,8$, Al nanocrystals were observed after the first stage of crystallization. An unknown intermetallic compound (IMC) crystallized after heat treatment of the $\mathrm{Al}_{85} \mathrm{Y}_{10} \mathrm{Ni}_{5}$ AMA. Besides, an increase of the $\mathrm{Y}$ content shifts the primary crystallization to higher temperatures.

Sahoo et al. [4] reported two stages of crystallization for $\mathrm{Al}_{94-\mathrm{x}} \mathrm{La}_{\mathrm{x}} \mathrm{Ni}_{6}(\mathrm{x}=4-7)$ AMAs. The primary crystallization leads to precipitation of $\mathrm{Al}$ (for $x=4,5$ ). The following stages lead to crystallization of $\mathrm{Al}$ and of an unknown intermetallic compound (for $\mathrm{x}=6$ ), or only of the unknown intermetallic compound (for $x=7$ ). The final stage of crystallization leads to precipitation of two phases $\left(\mathrm{La}_{3} \mathrm{Al}_{11}+\mathrm{NiAl}_{3}\right)$ for $\mathrm{x}=4-6$ and three phases $\left(\mathrm{La}_{3} \mathrm{Al}_{11}+\mathrm{NiAl}_{3}+\mathrm{Al}\right)$ for $\mathrm{x}=7$. Gao and Shiflet [5] reported three to five stages of crystallization for $\mathrm{Al}_{100-\mathrm{x}-\mathrm{y}} \mathrm{Gd}_{\mathrm{x}} \mathrm{Ni}_{\mathrm{y}} \quad(\mathrm{x}=3-12, \mathrm{y}=3-10) . \mathrm{Al}$ and an unknown IMC appeared at the first stage of crystallization of $\quad \mathrm{Al}_{87} \mathrm{Gd}_{10} \mathrm{Ni}_{3}, \quad \mathrm{Al}_{87} \mathrm{Gd}_{11} \mathrm{Ni}_{3}$, $\mathrm{Al}_{85} \mathrm{Gd}_{12} \mathrm{Ni}_{3}$ and $\mathrm{Al}_{85} \mathrm{Gd}_{8} \mathrm{Ni}_{7}$, while crystallization of $\mathrm{Al}$ was observed for the other alloys.

According to [6], the iron-containing alloy $\mathrm{Al}_{88} \mathrm{Y}_{7} \mathrm{Fe}_{5}$ crystallizes in three stages with precipitation of nanoparticles of $\mathrm{Al}$ at the first stage. Three stages of crystallization were observed for 
$\mathrm{Al}_{90} \mathrm{Y}_{5} \mathrm{Fe}_{5}, \mathrm{Al}_{85} \mathrm{Y}_{7.5} \mathrm{Fe}_{7.5}$ and $\mathrm{Al}_{80} \mathrm{Y}_{10} \mathrm{Fe}_{10}$ alloys with crystallizing of an IMC at the first stage [7]. Doping of ternary alloys by a fourth component allows changing their thermal stability and other parameters. Replacement of only 1 at.\% of $\mathrm{La}$ by $\mathrm{Ti}$ in an $\mathrm{Al}_{87} \mathrm{La}_{6} \mathrm{Ni}_{7}$ amorphous alloy prevents crystallization of unknown intermetallic phases and leads to crystallization of $\mathrm{Al}$ at the first stage of crystallization [8]. Replacement of 1 at.\% of $\mathrm{Ni}$ by $\mathrm{Cu}$ in the $\mathrm{Al}_{88} \mathrm{Sm}_{4} \mathrm{Ni}_{8}$ AMA shifts the primary crystallization of $\mathrm{Al}$ by about $17 \mathrm{~K}$ to higher temperatures [9]. Yang et al. [10] reported three stages of crystallization for $\mathrm{Al}_{85} \mathrm{Y}_{8-\mathrm{x}} \mathrm{Ni}_{5} \mathrm{Co}_{2} \mathrm{Fe}_{\mathrm{x}}(\mathrm{x}=0-5)$ with precipitation of $\mathrm{Al}$ at the 1-st and 2-nd stages for $\mathrm{x}=0,2$ and of binary and ternary intermetallic compounds (also metastable) for other alloys.

Analysis of [1-10] reveals that an increase of the content of rare-earth and/or transition metal element has a complex influence on the thermal stability and phase content of the alloys after crystallization. Summarizing the data presented above one can conclude that crystallization of AMAs strongly depends on the AMA content and is a complex process that needs additional investigations.

In our recent investigation [11] it was shown that partial substitution of $\mathrm{Fe}$ for $\mathrm{Ni}$ in the $\mathrm{Al}_{87} \mathrm{Y}_{5} \mathrm{Ni}_{8}$ alloy slows down the diffusion of $\mathrm{Al}$ atoms and shifts the crystallization to higher temperatures, while partial replacing of Y by Gd has the opposite effect.

The aim of the present work was to study the doping effect of another $R E$, Dy, and of the $3 d$-element $\mathrm{Fe}$ on the thermal stability of the $\mathrm{Al}_{87} \mathrm{Y}_{5} \mathrm{Ni}_{8}$ amorphous alloy. We will also focus on the thermal stability and crystallization process of the AMA as a function of the quantity of doping elements.

\section{Experimental procedure}

The basic amorphous alloy $\mathrm{Al}_{87} \mathrm{Y}_{5} \mathrm{Ni}_{8}$ and three other alloys: $\mathrm{Al}_{87} \mathrm{Dy}_{5} \mathrm{Ni}_{8}, \mathrm{Al}_{87} \mathrm{Y}_{4} \mathrm{Dy}_{1} \mathrm{Ni}_{8}$ and $\mathrm{Al}_{87} \mathrm{Dy}_{5} \mathrm{Fe}_{8}$, were prepared by the melt spinning technique in helium atmosphere, in the form of ribbons with a thickness of about $60 \mu \mathrm{m}$ and a width of $15 \mathrm{~mm}$. The melt was prepared from pure metals and binary $R E \mathrm{Al}_{3}$ $(R E=\mathrm{Y}, \mathrm{Dy})$ compounds. The purities of the initial metals were the following: $\mathrm{Al}-99.999$ wt.\%, Ni99.99 wt.\%, $\mathrm{Fe}-99.99$ wt.\%, Y - 99.96 wt.\%, and Dy - 99.99 wt.\%. Rare-earth metals in the form of binary compounds $R E \mathrm{Al}_{3}$ were primarily obtained by the arc-melting technique from metals of the same purity.

In order to study the crystallization of the above mentioned alloys the following experimental techniques were used:

1. Differential scanning calorimetry (DSC, PerkinElmer Pyris 1). The samples (about $15 \mathrm{mg}$ ) were encapsulated in aluminum capsules and heated up to $850 \mathrm{~K}$ at heating rates of 10,15 and $20 \mathrm{~K} / \mathrm{min}$. As reference plate the same empty aluminum capsule was used. The data were evaluated by applying the standard program Pyris.

2. X-ray diffraction (XRD, X'-Pert Philips PW 3040 diffractometer, $\mathrm{Cu} \mathrm{K}_{\alpha}$ radiation with a monochromator on the reflected beam, $2 \theta$ range: $10-140^{\circ}$, scanning step: $0.04^{\circ}$ ). This method was used for samples in the as-quenched state and annealed at elevated temperatures. Annealing was carried out for samples sealed into evacuated quartz tubes and heated at a heating rate of $20 \mathrm{~K} / \mathrm{min}$ up to the temperature corresponding to the end of the DSC peak, and then quenched in water. In order to determine the structure of the examined material, the Rietveld method was used (standard FullProf and PCW programs) [12,13]. X-ray diffraction data was also used for the calculation of the average crystallite size $( \pm 20 \%)$ by the Williamson-Hall method [14].

3. High-resolution electron microscopy (HREM, JEM 3010 electronic microscope). The microscopic observations were used in order to confirm (or not) the data obtained by the DSC and XRD techniques.

\section{Results and discussion}

Fig. 1 presents X-ray diffraction patterns obtained for the examined alloys in the as-quenched state. The profile confirms the amorphous state of the initial alloys.

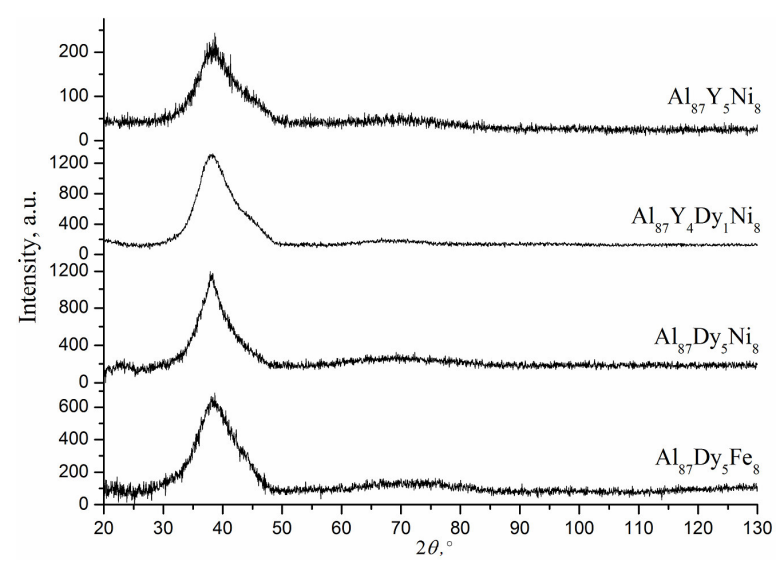

Fig. 1 XRD patterns of the initial amorphous alloys with Dy $(\mathrm{Cu} \mathrm{K})$.

\subsection{DSC study of amorphous alloys}

Fig. 2 presents DSC curves obtained for the amorphous alloys containing Dy with a heating rate of $20 \mathrm{~K} / \mathrm{min}$. The Fe-free alloys crystallize in three stages. The first maximum, corresponding to the primary crystallization of the AMA, takes place in the temperature range $442-527 \mathrm{~K}$.

Partial replacement of Y by Dy (1 at.\%) causes a shift of the first DSC maximum to lower temperatures by $22 \mathrm{~K}$, which can be interpreted as a reduction of the thermal stability of the AMA. Complete substitution of Dy for $\mathrm{Y}$ decreases the temperature of primary 
crystallization by another $21 \mathrm{~K}$. Replacement of 8 at.\% of $\mathrm{Ni}$ by Fe severely changes the shape of the DSC curve and improves the thermal stability of the AMA by more than $100 \mathrm{~K}$. This alloy crystallizes in 5 stages. The last DSC maximum, at about $780 \mathrm{~K}$, is very broad and shallow in comparison with the other ones, as it is seen from Fig. 2b. Characteristic temperatures of the DSC maxima are presented in Table 1.

In our previous work [11] on $\mathrm{Al}_{87} R E_{5} T M_{8}$ alloys with $R E=\mathrm{Y}, \mathrm{Gd}$ we did not present results on the activation energy of crystallization of the amorphous alloys. These results are presented in the present work, discussed in details and compared with those obtained for the Dy-containing AMAs.

The activation energy was determined according to the Kissinger equation [15] for heating rates of 10,15 and $20 \mathrm{~K} / \mathrm{min}$ from the slope of the curve $\ln \left(\mathrm{b} / T_{\mathrm{p}}\right) v s$. $1 / T_{\mathrm{p}}$; where $\mathrm{b}$ is the heating rate and $T_{\mathrm{p}}$ is the maximum temperature of the peak. These curves, plotted in Fig. 3 for each of the exothermic reactions, show linear dependencies. The activation energies were determined from the Kissinger plots for all the investigated alloys (see Table 2).
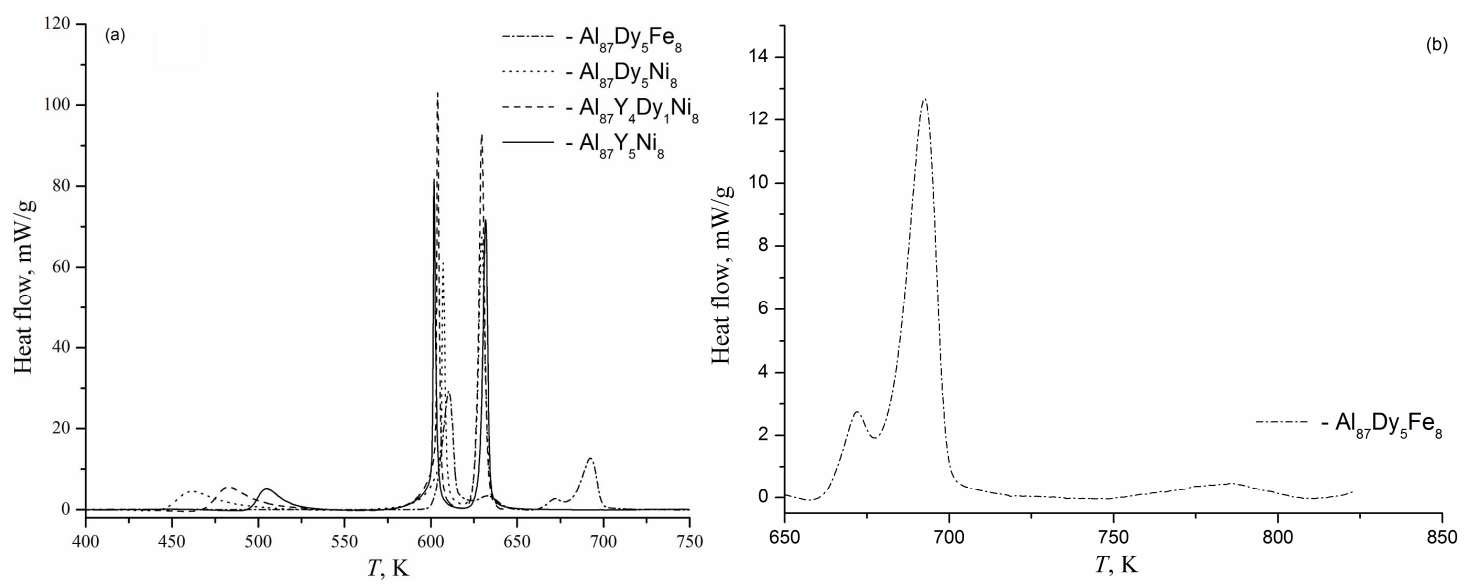

Fig. 2 (a) DSC curves for $\mathrm{Al}_{87} R E_{5} T M_{8}(R E=\mathrm{Y}, \mathrm{Dy} ; T M=\mathrm{Fe}, \mathrm{Ni})$ amorphous alloys obtained at a heating rate of $20 \mathrm{~K} / \mathrm{min}$; (b) final stages (III, IV and V) of crystallization of the $\mathrm{Al}_{87} \mathrm{Dy}_{5} \mathrm{Fe}_{8} \mathrm{AMA}$.

Table 1 The characteristic temperatures of the DSC curves of AMAs: $T_{1 \max }, T_{2 \max }, T_{3 \max }, T_{4 \max }, T_{5 \max }$ are the maximum temperatures of the first, second, third, fourth, and fifth exothermal peaks.

\begin{tabular}{l|c|c|c|c|c}
\hline $\mathrm{AMA}$ & $T_{1 \max }, \mathrm{K}$ & $T_{2 \max }, \mathrm{K}$ & $T_{3 \max }, \mathrm{K}$ & $T_{4 \max }, \mathrm{K}$ & $\mathrm{T}_{5 \max }, \mathrm{K}$ \\
\hline $\mathrm{Al}_{87} \mathrm{Y}_{5} \mathrm{Ni}_{8}{ }^{\mathrm{a}}$ & 505 & 602 & 632 & - & - \\
$\mathrm{Al}_{87} \mathrm{Y}_{4} \mathrm{Dy}_{1} \mathrm{Ni}_{8}$ & 483 & 604 & 630 & - & - \\
$\mathrm{Al}_{87} \mathrm{Dy}_{5} \mathrm{Ni}_{8}$ & 462 & 607 & 629 & - & - \\
$\mathrm{Al}_{87} \mathrm{Dy}_{5} \mathrm{Fe}_{8}$ & 611 & 633 & 672 & 693 & 786 \\
\hline
\end{tabular}

${ }^{a}$ data taken from [11]

Table 2 Activation energy $E_{\mathrm{a}, 1-5}$ corresponding to the crystallization stages of $\mathrm{Al}_{87} R E_{5} T M_{8}(R E=\mathrm{Y}, \mathrm{Gd}, \mathrm{Dy}$; $T M=\mathrm{Fe}, \mathrm{Ni}$ ) amorphous alloys (in $\mathrm{kJ} / \mathrm{mol}$ ).

\begin{tabular}{l|c|c|c|c|c}
\hline $\mathrm{AMA}$ & $E_{\mathrm{a}, 1}$ & $E_{\mathrm{a}, 2}$ & $E_{\mathrm{a}, 3}$ & $E_{\mathrm{a}, 4}$ & $E_{\mathrm{a}, 5}$ \\
\hline $\mathrm{Al}_{87} \mathrm{Y}_{5} \mathrm{Ni}_{8}$ & $203 \pm 29$ & $261 \pm 24$ & $221 \pm 12$ & - & - \\
$\mathrm{Al}_{87} \mathrm{Y}_{4} \mathrm{Gd}_{1} \mathrm{Ni}_{8}$ & $146 \pm 5$ & $255 \pm 27$ & $204 \pm 15$ & - & - \\
$\mathrm{Al}_{87} \mathrm{Gd}_{5} \mathrm{Ni}_{8}$ & $199 \pm 5$ & $268 \pm 1$ & $213 \pm 1$ & - & - \\
$\mathrm{Al}_{87} \mathrm{Gd}_{5} \mathrm{Ni}_{4} \mathrm{Fe}_{4}$ & $256 \pm 15$ & $333 \pm 21$ & $227 \pm 8$ & - & - \\
$\mathrm{Al}_{87} \mathrm{Y}_{4} \mathrm{Gd}_{1} \mathrm{Ni}_{4} \mathrm{Fe}_{4}$ & $241 \pm 5$ & $317 \pm 5$ & $233 \pm 6$ & - & - \\
$\mathrm{Al}_{87} \mathrm{Y}_{4} \mathrm{Dy}_{1} \mathrm{Ni}_{8}$ & $194 \pm 5$ & $265 \pm 13$ & $207 \pm 6$ & - & - \\
$\mathrm{Al}_{87} \mathrm{Dy}_{5} \mathrm{Ni}_{8}$ & $163 \pm 2$ & $267 \pm 5$ & $209 \pm 2$ & - & - \\
$\mathrm{Al}_{87} \mathrm{Dy}_{5} \mathrm{Fe}_{8}$ & $267 \pm 1$ & $176 \pm 7$ & $207 \pm 1$ & $178 \pm 1$ & $420 \pm 51$ \\
\hline
\end{tabular}



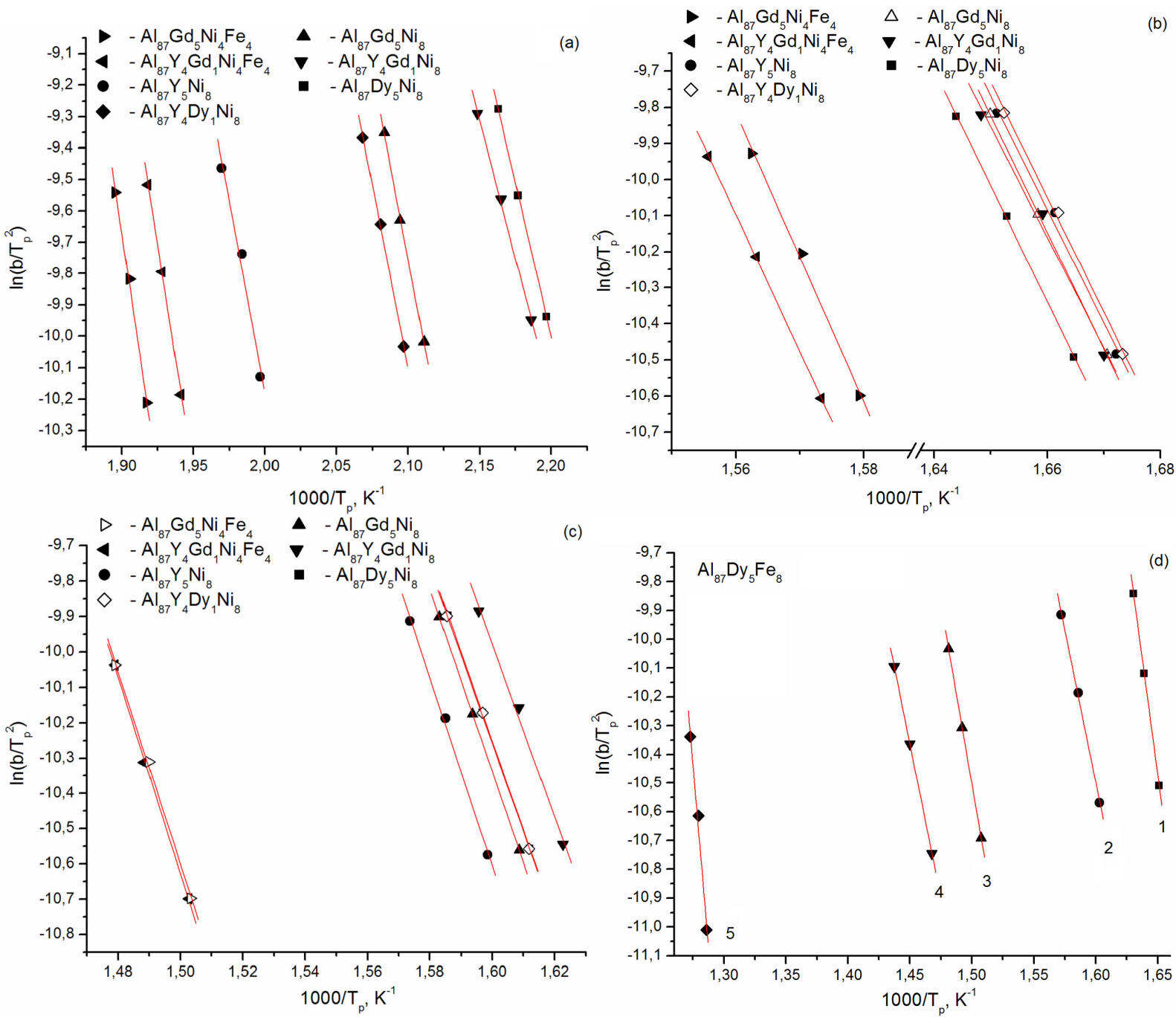

(b)

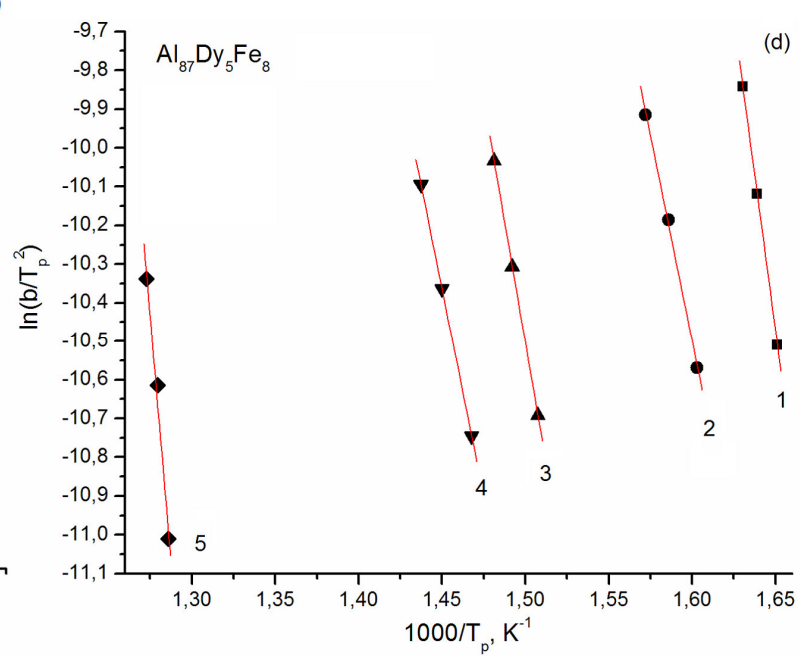

Fig. 3 Kissinger plots for the first (a), second (b) and third (c) exothermic DSC peaks for the Ni-containing $\mathrm{Al}_{87} R E_{5} T M_{8}(R E=\mathrm{Y}, \mathrm{Gd}, \mathrm{Dy} ; T M=\mathrm{Fe}, \mathrm{Ni})$ alloys and for the five DSC exothermic peaks (1-5) for the $\mathrm{Al}_{87} \mathrm{Dy}_{5} \mathrm{Fe}_{8}$ amorphous alloy (d).

\subsection{XRD and HREM study of alloys}

In order to study the primary crystallization of the AMAs the examined samples were sealed into evacuated quartz tubes and were heated at a heating rate of $20 \mathrm{~K} / \mathrm{min}$ to the temperature of the end of the first DSC maximum, and then quenched in water. The obtained XRD patterns for the $\mathrm{Al}_{87} \mathrm{Y}_{4} \mathrm{Dy}_{1} \mathrm{Ni}_{8}$ and $\mathrm{Al}_{87} \mathrm{Dy}_{5} \mathrm{Ni}_{8}$ alloys are presented in Fig. 4 .

According to the XRD data the first stage of crystallization can be attributed to formation of $\mathrm{Al}$ nanograins. Analysis of the XRD spectra obtained for these samples shows that the unit cell parameters of the observed $\mathrm{Al}$ phase in both cases are slightly larger than for pure $\mathrm{Al}(0.40494 \mathrm{~nm})$ : $0.4056(1) \mathrm{nm}$ for $\mathrm{Al}_{87} \mathrm{Dy}_{5} \mathrm{Ni}_{8}$ and $0.40522(7) \mathrm{nm}$ for $\mathrm{Al}_{87} \mathrm{Y}_{4} \mathrm{Dy}_{1} \mathrm{Ni}_{8}$. This probably means that the heat treatment causes formation of a solid solution $\mathrm{Al}(R E)$. However, this fact does not object to the possible segregation of $R E$-elements at the Al-nanocrystals/amorphous matrix boundaries, as reported by Hono et al. [16].
Additional examinations were performed on samples annealed for $1 \mathrm{~h}$ at $518 \mathrm{~K}$ for $\mathrm{Al}_{87} \mathrm{Dy}_{5} \mathrm{Ni}_{8}$ and $527 \mathrm{~K}_{\text {for }} \mathrm{Al}_{87} \mathrm{Y}_{4} \mathrm{Dy}_{1} \mathrm{Ni}_{8}$. Fig. 5 presents results for the $1 \mathrm{~h}$-heat treated $\mathrm{Al}_{87} \mathrm{Dy}_{5} \mathrm{Ni}_{8}$ AMA. One can notice that $\mathrm{Al}(R E)$ nanograins (dark black, approximate size $20 \mathrm{~nm}$ ) are scatted randomly in an amorphous matrix. The crystallite sizes calculated from the XRD data by applying the Williamson-Hall method are close to those obtained from the HREM data (see Table 3). The volume fractions of the $\mathrm{Al}$ nanocrystalline phase after different stages of crystallization are also presented (see Table 4).

One can see dark grains of $\mathrm{Al}(R E)$ on Fig. 5 and both light and gray regions of amorphous matrix. Such splitting of the amorphous matrix into two parts could be related to different distributions of rare-earth elements. Another possibility could concern the formation of primary and secondary induced $\mathrm{Al}$-nanocrystals after $1 \mathrm{~h}$ heat treatment. If this is true, the three fields (primary and secondary Al- 


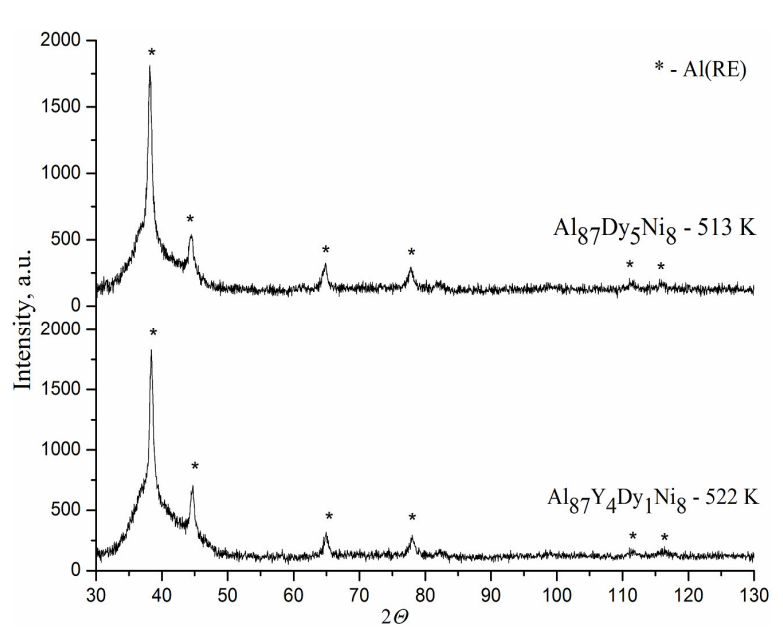

Fig. 4 XRD patterns of amorphous alloys heated up to different temperatures after having reached the first stage of crystallization.

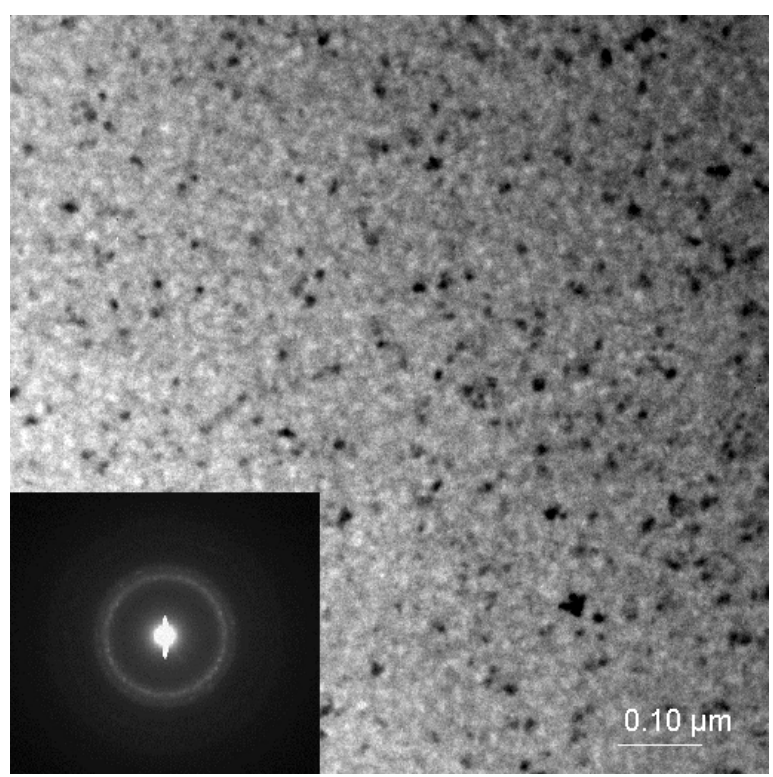

Fig. 5 HREM image of the $\mathrm{Al}_{87} \mathrm{Dy}_{5} \mathrm{Ni}_{8}$ AMA heat-treated at $518 \mathrm{~K}$ for $1 \mathrm{~h}$.

Table 3 The crystallite size $(D)$ and average microstrain $(\varepsilon \pm 0.5)$ of the $\operatorname{Al}(R E)$ grains for $\mathrm{Al}_{87} \mathrm{Y}_{5-\mathrm{x}} \mathrm{Dy}_{\mathrm{x}} \mathrm{Ni}_{8}(\mathrm{x}=0,1,5)$ AMAs heated at $20 \mathrm{~K} / \mathrm{min}$ to the annealing temperature $T_{\mathrm{ann}}$.

\begin{tabular}{l|c|c|c|c|c|c}
\hline \multirow{2}{*}{ AMA } & \multicolumn{2}{|c|}{ I-st stage of crystallization } & \multicolumn{3}{c}{ II-nd stage of crystallization } \\
\cline { 2 - 7 } & $\begin{array}{c}\text { Annealing } \\
\text { temperature } \\
T_{\text {ann }}, \mathrm{K}\end{array}$ & $\begin{array}{c}\text { Crystallite } \\
\text { size } \\
D, \mathrm{~nm}\end{array}$ & $\begin{array}{c}\text { Microstrain, } \\
\%\end{array}$ & $\begin{array}{c}\text { Annealing } \\
\text { temperature } \\
T_{\text {ann }}, \mathrm{K}\end{array}$ & $\begin{array}{c}\text { Crystallite } \\
\text { size }\end{array}$ & $\begin{array}{c}\text { Microstrain, } \\
\%\end{array}$ \\
\hline $\mathrm{Al}_{87} \mathrm{Y}_{5} \mathrm{Ni}_{8}$ & 512 & 15 & 2 & 612 & 30 & 2 \\
$\mathrm{Al}_{87} \mathrm{Y}_{4} \mathrm{Dy}_{1} \mathrm{Ni}_{8}$ & 522 & 20 & 3 & 615 & 60 & 3 \\
$\mathrm{Al}_{87} \mathrm{Dy}_{5} \mathrm{Ni}_{8}$ & 513 & 25 & 2 & 618 & 35 & 2 \\
\hline
\end{tabular}

Table 4 The volume fraction of nanocrystals after stage I and II of crystallization.

\begin{tabular}{l|c|c}
\hline \multirow{2}{*}{ AMA } & \multicolumn{2}{|c}{ Volume fraction of $\mathrm{Al}(R E)$ nanocrystals $( \pm 0.05)$} \\
\cline { 2 - 3 } & I-st stage & II-nd stage \\
\hline $\mathrm{Al}_{87} \mathrm{Y}_{5} \mathrm{Ni}_{8}$ & 0.28 & 0.39 \\
$\mathrm{Al}_{87} \mathrm{Y}_{4} \mathrm{Dy}_{1} \mathrm{Ni}_{8}$ & 0.32 & 0.45 \\
$\mathrm{Al}_{87} \mathrm{Dy}_{5} \mathrm{Ni}_{8}$ & 0.34 & 0.51 \\
\hline
\end{tabular}

nanocrystals and the remaining amorphous matrix) are observed on the HREM image.

XRD spectra of the amorphous alloys containing Dy, heated up to temperatures after the second DSC peak, are shown in Fig. 6. The patterns are similar: in all the cases Al diffraction lines and diffuse scattering (which is attributed to the remaining amorphous matrix) are observed.

$\mathrm{X}$-ray diffraction patterns obtained for the $\mathrm{Al}_{87} \mathrm{Dy}_{5} \mathrm{Ni}_{8}$ and $\mathrm{Al}_{87} \mathrm{Y}_{4} \mathrm{Dy}_{1} \mathrm{Ni}_{8}$ AMAs after the third stage of crystallization are presented in Fig. 7. For these alloys it is the final stage of crystallization. The XRD patterns contain reflections from two phases: $\mathrm{Al}(R E)$ solid solution and a ternary compound $R E_{3} \mathrm{Ni}_{5} \mathrm{Al}_{19}$ with $\mathrm{Gd}_{3} \mathrm{Ni}_{5} \mathrm{Al}_{19}$-type structure [17].

As can be seen from Table 5, the lattice parameters of the $\mathrm{Al}$ grains, refined from the XRD patterns, decrease from the first to the third stages of crystallization, but in all cases they are larger than for pure Al $(0.40494 \mathrm{~nm})$, which could indicate the formation of a solid solution $\mathrm{Al}(R E)$. The decrease of the lattice parameters of $\mathrm{Al}(R E)$ could be related to the formation of pure Al-nanocrystals at the second stage of crystallization.

Results of the Rietveld profile refinement of the XRD data for the $\mathrm{Al}_{87} \mathrm{Dy}_{5} \mathrm{Ni}_{8}$ alloy are presented in Fig. 8. The XRD profile and the refined cell 
parameters for the $\mathrm{Dy}_{3} \mathrm{Ni}_{5} \mathrm{Al}_{19}$ intermetallic compound $(a=0.40685(5) \mathrm{nm}, \quad b=1.5941(2) \mathrm{nm}$, $c=2.6975(3) \mathrm{nm})$ are in good agreement with literature data: $a=0.40893(7) \mathrm{nm}, b=1.5993(2) \mathrm{nm}$, $c=2.7092(4) \mathrm{nm}[17]$.

The crystallization path of the $\mathrm{Al}_{87} \mathrm{Dy}_{5} \mathrm{Fe}_{8}$ alloy differs completely from those of the two other investigated Dy-alloys, as can be seen from Fig. 9. Crystallization occurs in 5 stages. The first stage of crystallization is attributed to the formation of an unidentified intermetallic compound (or compounds). It is marked as $\sigma$-phase. After the second stage of

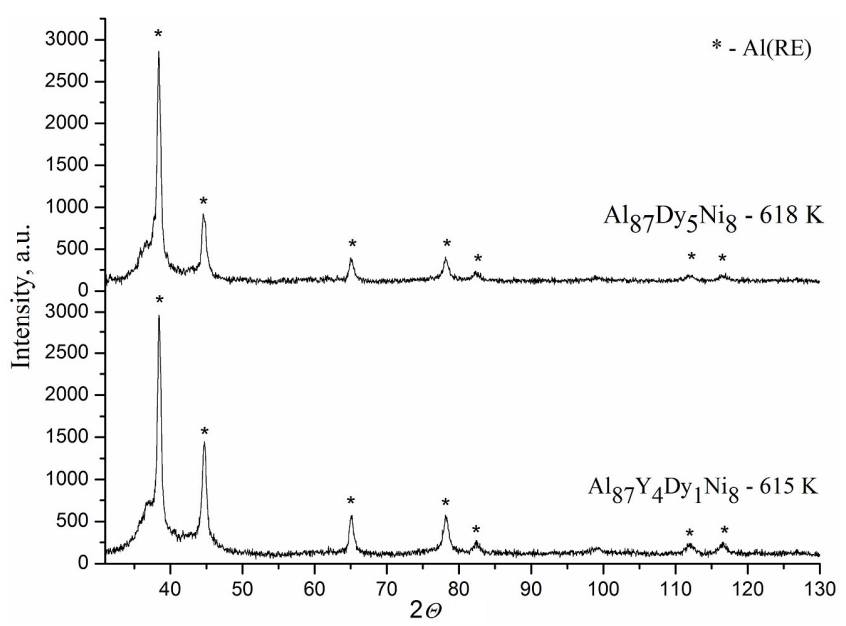

Fig. 6 XRD patterns of amorphous alloys heated up to different temperatures after having reached the second stage of crystallization. crystallization the AMA consists of $\mathrm{Al}(\mathrm{Dy})$, the IMC $\mathrm{DyFe}_{4} \mathrm{Al}_{8}$ with $\mathrm{CeMn}_{4} \mathrm{Al}_{8}$-type structure and the unidentified compound ( $\sigma$-phase) from the previous stage of crystallization. The third stage of crystallization is attributed to the formation of $\mathrm{Al}(\mathrm{Dy})$ and the IMC $\mathrm{DyFe}_{4} \mathrm{Al}_{8}$. The $\sigma$-phase decomposes, while traces of another unidentified IMC ( $\mu$-phase) appear in the XRD pattern. The XRD patterns corresponding to the fourth and fifth stage of crystallization indicate the following phase content: $\mathrm{Al}(\mathrm{Dy})$, the IMC $\mathrm{DyFe}_{2} \mathrm{Al}_{10}$ with $\mathrm{YbFe}_{2} \mathrm{Al}_{10}$-type structure and the $\mu$-phase. The fourth stage of

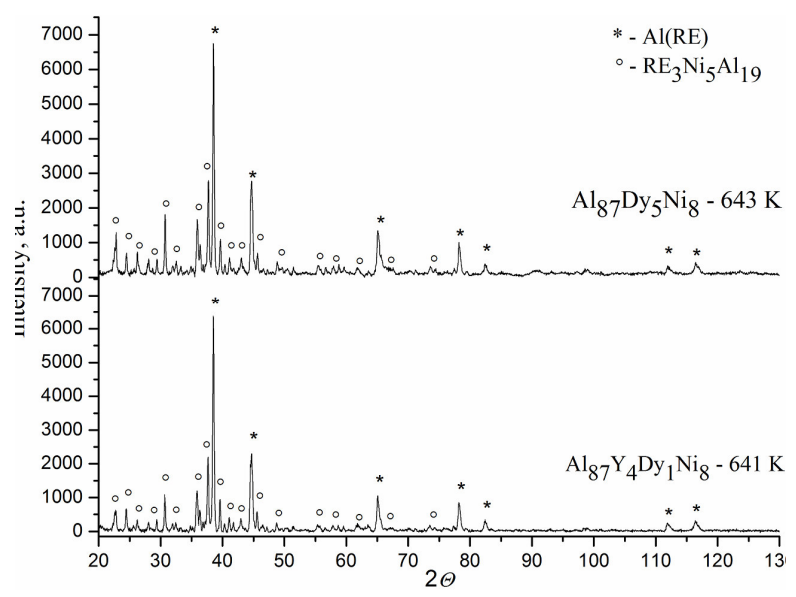

Fig. 7 XRD patterns of amorphous alloys heated up to different temperatures after having reached the third stage of crystallization.

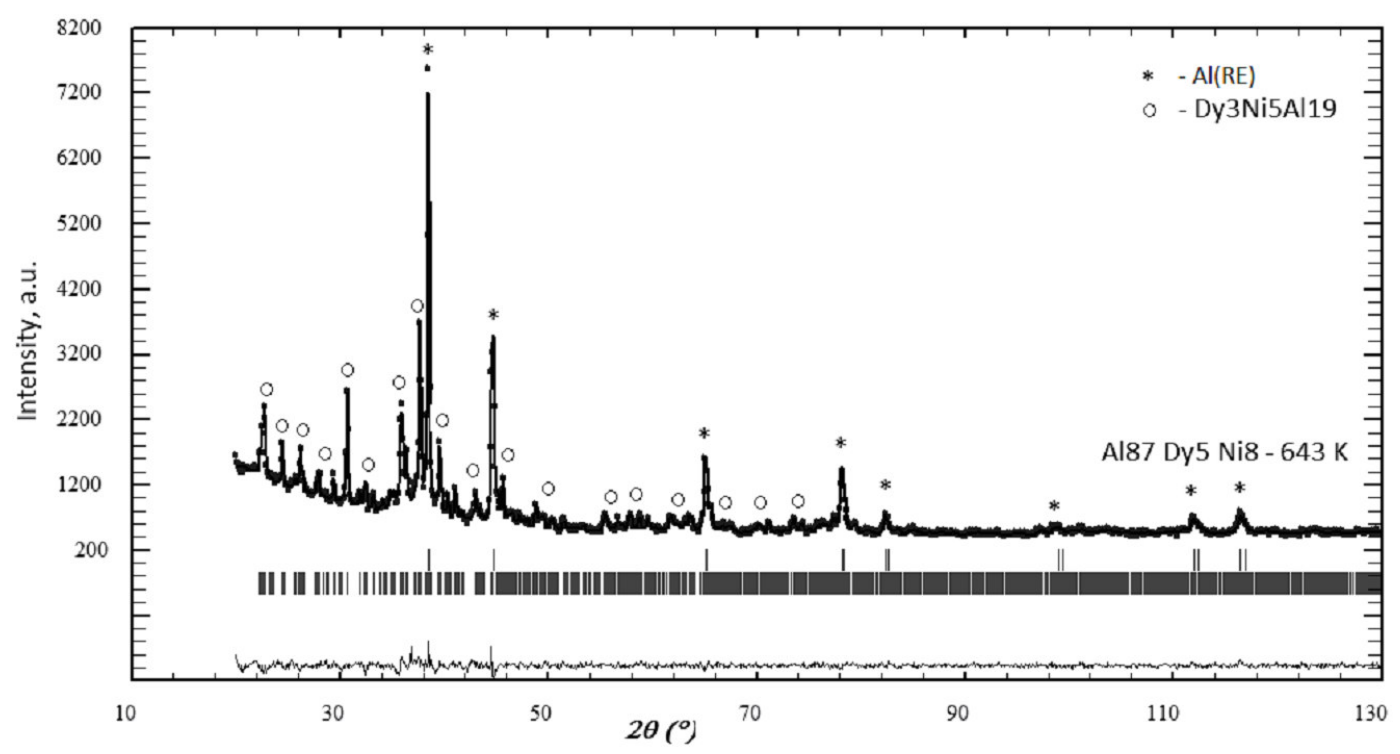

Fig. 8 XRD pattern obtained for the $\mathrm{Al}_{87} \mathrm{Dy}_{5} \mathrm{Ni}_{8}$ alloy after the third stage of crystallization and results of the Rietveld refinement (dots and line are experimental and theoretical data, respectively; the difference diagram is shown at the bottom; ${ }^{*}-\mathrm{Al}(R E), \circ-\mathrm{Dy}_{3} \mathrm{Ni}_{5} \mathrm{Al}_{19}$, residuals $\mathrm{R}_{\mathrm{p}}=3.29 \%, \mathrm{R}_{\mathrm{wp}}=4.24 \%, \mathrm{GoF}=1.19$ ). 


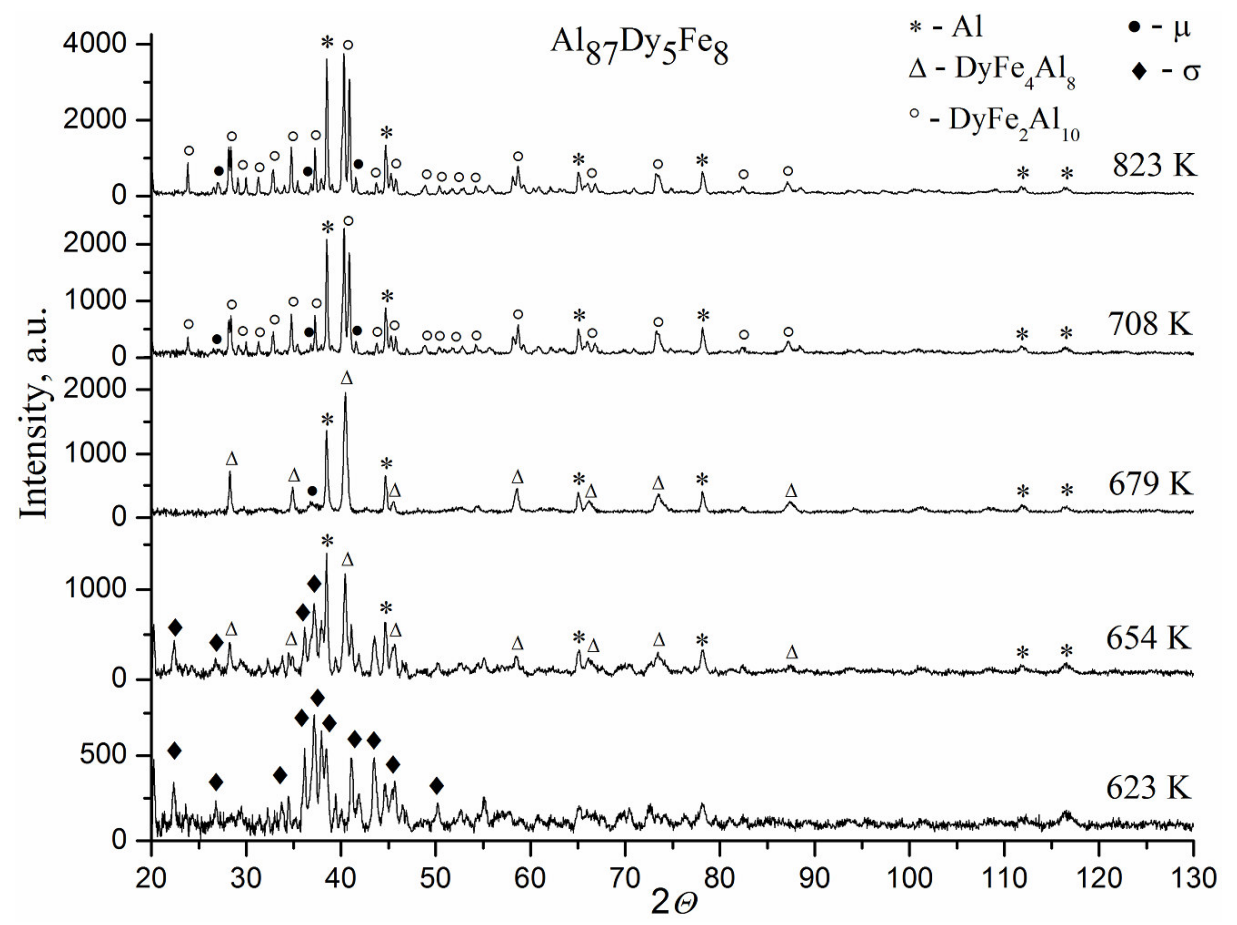

Fig. 9 XRD patterns of $\mathrm{Al}_{87} \mathrm{Dy}_{5} \mathrm{Fe}_{8}$ amorphous alloys heated up to different temperatures after 1-5 stages of crystallization.

Table 5 Lattice parameters of $\mathrm{Al}(R E)$ after stage I, II and III of crystallization (in $\mathrm{nm}$ ).

\begin{tabular}{l|c|c|c}
\hline $\mathrm{AMA}$ & I-st stage & II-nd stage & III-rd stage \\
\hline $\mathrm{Al}_{87} \mathrm{Y}_{5} \mathrm{Ni}_{8}{ }^{\mathrm{a}}$ & $0.4059(2)$ & $0.4055(1)$ & $0.40522(6)$ \\
$\mathrm{Al}_{87} \mathrm{Y}_{4} \mathrm{Dy}_{1} \mathrm{Ni}_{8}$ & $0.4061(3)$ & $0.40557(7)$ & $0.40527(4)$ \\
$\mathrm{Al}_{87} \mathrm{Dy}_{5} \mathrm{Ni}_{8}$ & $0.4064(2)$ & $0.40544(5)$ & $0.40518(3)$ \\
\hline
\end{tabular}

${ }^{\mathrm{a}}$ data taken from [11]

crystallization probably corresponds to decomposition of the $\mathrm{DyFe}_{4} \mathrm{Al}_{8}$ intermetallic compound. The last exothermic effect is very small (see Fig. 2b). Based on this, one can conclude that the last (fifth) exothermic DSC maximum for the $\mathrm{Al}_{87} \mathrm{Dy}_{5} \mathrm{Fe}_{8}$ amorphous alloy corresponds to crystallization of the remaining amorphous phases, with the same products of crystallization as mentioned earlier.

The last crystallization stage of the Fe-free $\mathrm{Al}_{87} R E_{5} \mathrm{Ni}_{8}$ alloys occurs in the temperature range $621-639 \mathrm{~K}$, while for the $\mathrm{Al}_{87} \mathrm{Dy}_{5} \mathrm{Fe}_{8}$ alloy this temperature range is considerably higher: $750-808 \mathrm{~K}$ (see Fig. 2). Partial replacement of $\mathrm{Y}$ by Dy $\left(\mathrm{Al}_{87} \mathrm{Y}_{5} \mathrm{Ni}_{8} \rightarrow \mathrm{Al}_{87} \mathrm{Y}_{4} \mathrm{Dy}_{1} \mathrm{Ni}_{8}\right)$ shifts $T_{1 \max }$ to lower temperatures by about $20 \mathrm{~K}$ (see Table 1). Total replacement of $\mathrm{Y}$ by Dy $\left(\mathrm{Al}_{87} \mathrm{Y}_{5} \mathrm{Ni}_{8} \rightarrow \mathrm{Al}_{87} \mathrm{Dy}_{5} \mathrm{Ni}_{8}\right)$ causes an additional shift of this maximum by $22 \mathrm{~K}$. As reported previously [11], the doping effect of another $R E, \mathrm{Gd}$, is similar. Partial substitution of $\mathrm{Gd}$ for $\mathrm{Y} \quad\left(\mathrm{Al}_{87} \mathrm{Y}_{5} \mathrm{Ni}_{8} \rightarrow \quad \mathrm{Al}_{87} \mathrm{Y}_{4} \mathrm{Gd}_{1} \mathrm{Ni}_{8}\right)$ shifts the crystallization to lower temperatures (from $505 \mathrm{~K}$ to
$462 \mathrm{~K})$ and total substitution of $\mathrm{Gd}$ for $\mathrm{Y}$ $\left(\mathrm{Al}_{87} \mathrm{Y}_{5} \mathrm{Ni}_{8} \rightarrow \mathrm{Al}_{87} \mathrm{Gd}_{5} \mathrm{Ni}_{8}\right)$ shifts it down to $478 \mathrm{~K}$.

As it can be seen from Table 2, partial and complete substitution of $\mathrm{Fe}$ for $\mathrm{Ni}$ causes a significant increase of the activation energy $E_{\mathrm{a}, 1}$ with respect to the basic alloy $\mathrm{Al}_{87} \mathrm{Y}_{5} \mathrm{Ni}_{8}$. Partial replacement of $\mathrm{Y}$ by Gd has the opposite effect (the activation energy $E_{\mathrm{a}, 1}$ decreases significantly), but complete replacement of $\mathrm{Y}$ by $\mathrm{Gd}$ causes almost no further change of $E_{\mathrm{a}, 1}$. Partial replacement of $Y$ by Dy causes minor changes of $E_{\mathrm{a} 1}$, while the complete replacement of Y by Dy reduces it significantly.

The second crystallization stage is characterized by approximately the same activation energy $E_{\mathrm{a}, 2}$ for all the alloys containing no $\mathrm{Fe}$, approximately 265-270 kJ/mol. For the alloys containing Fe (except the $\mathrm{Al}_{87} \mathrm{Dy}_{5} \mathrm{Fe}_{8}$ alloy), $E_{\mathrm{a}, 2}$ is also approximately the same. For the third (and final) stage of crystallization of the investigated AMAs there are similar tendencies as for the second stage: the value of the activation energy is approximately the same for all the alloys 
without $\mathrm{Fe}$ and is equal to $\sim 210-220 \mathrm{~kJ} / \mathrm{mol}$ whereas for the alloys with $\mathrm{Fe}$ it is slightly higher, $\sim 230 \mathrm{~kJ} / \mathrm{mol}$.

Comparing the crystallization temperature, activation energy of crystallization and phase content for different AMAs (except the $\mathrm{Al}_{87} \mathrm{Dy}_{5} \mathrm{Fe}_{8}$ alloy), it can be seen (Table 1) that doping of the reference $\mathrm{Al}_{87} \mathrm{Y}_{5} \mathrm{Ni}_{8}$ alloy by other $R E$ elements reduces the temperature of primary crystallization, while Fe-doping increases it considerably. It should also be noted that the values of the activation energy of the second stage of crystallization (Table 2) are almost the same and do practically not depend on the $R E$ element. This means that the $R E$ elements play a key role at the first stage of crystallization. The X-ray analysis shows the formation of an $\operatorname{Al}(R E)$ solid solution at the first two stages of crystallization for the $\mathrm{Ni}$-containing alloys. These results can be interpreted as formation of $\mathrm{Al}(R E)$ nanocrystals from an amorphous matrix at the first stage of crystallization and thermally induced crystallization at the second stage of crystallization (when additional energy of nucleation is needed). Contrary to the doping effect of the $R E, \mathrm{Fe}$ slows down the diffusion of atoms at all crystallization stages and takes part in the crystallization only at the final stages.

The crystallization path of the $\mathrm{Al}_{87} \mathrm{Dy}_{5} \mathrm{Fe}_{8}$ amorphous alloy differs completely from those of the Ni-containing alloys. Its crystallization occurs in 5 stages. It may be noted that the similar alloy with $\mathrm{Ni}$, $\mathrm{Al}_{87} \mathrm{Dy}_{5} \mathrm{Ni}_{8}$ crystallizes in three stages.

The atomic ratio of the transition and rare-earth metal is almost the same for the amorphous alloys $\mathrm{Al}_{87} R E_{5} \mathrm{Ni}_{8}$ (TM:RE = 1:0.625) and the crystallized ternary IMC $R E_{3} \mathrm{Ni}_{5} \mathrm{Al}_{19}(T M: R E=1: 0.6)$. For the crystallization of the IMC from the amorphous matrix there is an excess of $\mathrm{Al}$ and a small excess of $R E$ in the $\mathrm{Al}_{87} R E_{5} \mathrm{Ni}_{8}$ AMA, which crystallizes as a solid solution $\mathrm{Al}(R E)$. The composition of the $\mathrm{Al}_{87} \mathrm{Y}_{5} \mathrm{Ni}_{8}$ alloy corresponds to the two-phase equilibrium $\left.<\mathrm{Al}+\mathrm{Y}_{3} \mathrm{Ni}_{5} \mathrm{Al}_{19}\right\rangle$, according to the equilibrium phase diagram of the ternary system $\mathrm{Y}-\mathrm{Ni}-\mathrm{Al}$ [18]. The crystallization path of this amorphous alloy occurs by an equilibrium mechanism and corresponds to the $\mathrm{Y}-\mathrm{Ni}-\mathrm{Al}$ phase diagram.

According to the $\mathrm{XRD}$ results the crystallization path of the $\mathrm{Al}_{87} \mathrm{Dy}_{5} \mathrm{Fe}_{8}$ amorphous alloy can be described by the following scheme:

$\mathrm{AMA} \rightarrow(\mathrm{amo})+\sigma \rightarrow \mathrm{Al}(\mathrm{Dy})+\mathrm{DyFe}_{4} \mathrm{Al}_{8}+\sigma \rightarrow$ $\mathrm{Al}(\mathrm{Dy})+\mathrm{DyFe}_{4} \mathrm{Al}_{8}+\mu \rightarrow \mathrm{Al}(\mathrm{Dy})+\mathrm{DyFe}_{2} \mathrm{Al}_{10}+\mu$.

As it was described earlier, the ratio between the content of transition metal and rare-earth metal for the amorphous alloy $\mathrm{Al}_{87} \mathrm{Dy}_{5} \mathrm{Fe}_{8}(T M: R E=1: 0.625)$ is higher than for the crystalline IMCs $\mathrm{DyFe}_{4} \mathrm{Al}_{8}$ $(T M: R E=1: 0.25)$ and $\mathrm{DyFe}_{2} \mathrm{Al}_{10}(T M: R E=1: 0.5)$. So, it is possible to deduce that the $\sigma$-phase, which appears at the first stage of crystallization, is a phase containing a larger amount of rare-earth metal. The second stage of crystallization is attributed to decomposition of the amorphous matrix (amo) into $\mathrm{Al}$ (Dy) and $\mathrm{DyFe}_{4} \mathrm{Al}_{8}$. The following (3-rd) stage of crystallization corresponds to decomposition of the rare-earth rich $\sigma$-phase into $\mathrm{Al}(\mathrm{Dy})$, a residual unidentified IMC ( $\mu$-phase) and $\mathrm{DyFe}_{4} \mathrm{Al}_{8}$. The fourth stage of crystallization is attributed to decomposition of the IMC $\mathrm{DyFe}_{4} \mathrm{Al}_{8}$ into $\mathrm{DyFe}_{2} \mathrm{Al}_{10}, \mathrm{Al}(\mathrm{Dy})$ and $\mu$-phase. The IMC DyFe $\mathrm{Al}_{10}$ contains twice less Fe than $\mathrm{DyFe}_{4} \mathrm{Al}_{8}$, and the excess of $\mathrm{Fe}$ probably crystallizes as a Fe-rich intermetallic compound $(\mu)$.

Investigations for the identification of the $\sigma$ - and $\mu$-phases are in progress.

\section{Conclusions}

Thermally induced crystallization of $\mathrm{Al}_{87} \mathrm{Y}_{5} \mathrm{Ni}_{8}$ amorphous alloys doped with Dy and Fe has been investigated.

The Ni-containing alloys $\mathrm{Al}_{87} \mathrm{Y}_{4} \mathrm{Dy}_{1} \mathrm{Ni}_{8}$ and $\mathrm{Al}_{87} \mathrm{Dy}_{5} \mathrm{Ni}_{8}$ crystallize in 3 stages. Replacement of $\mathrm{Y}$ by $\mathrm{Dy}(\mathrm{Gd})$ shifts the primary crystallization to lower temperatures and decreases the crystallization activation energy. The $R E$ elements play a dominant role at the first stage of crystallization. The first two stages of crystallization of the AMAs without Fe were attributed to the formation of nanograins of $\mathrm{Al}(R E)$ solid solution. At the third, final stage, precipitation of the ternary compounds $R E_{3} \mathrm{Ni}_{5} \mathrm{Al}_{19}$ with orthorhombic $\mathrm{Gd}_{3} \mathrm{Ni}_{5} \mathrm{Al}_{19}$-type structure occurs.

The Fe-containing amorphous alloy $\mathrm{Al}_{87} \mathrm{Dy}_{5} \mathrm{Fe}_{8}$ crystallizes in 5 stages. Fe-doping slows down the diffusion of $\mathrm{Al}$ atoms in the amorphous matrix and increases the thermal stability of the amorphous alloys by about $100 \mathrm{~K}$ and increases the activation energy of primary crystallization. Complete crystallization of the $\mathrm{Al}_{87} \mathrm{Dy}_{5} \mathrm{Fe}_{8}$ AMA leads to the formation of two unidentified intermetallic compounds $(\sigma$ and $\mu)$ and two other IMC with $\mathrm{CeMn}_{4} \mathrm{Al}_{8}$ - and $\mathrm{YbFe}_{2} \mathrm{Al}_{10}$-type structures.

\section{Acknowledgements}

The work was supported in part by the Ministry of Education and Science of Ukraine, Grant No. 0109 U002087.

\section{References}

[1] A. Inoue, Progr. Mater. Sci. 43 (1998) 365-520.

[2] L. Battezzati, S. Pozzovivo, P. Rizzi, In: H.S. Nalwa (Eds.), Nanoclusters and Nanocrystals, Am. Sci. Publ., 2003, pp. 283-309.

[3] S. Saini, A. Zaluska, Z. Altounian, J. Non-Cryst. Solids 250-252 (1999) 714-718.

[4] K.L. Sahoo, M. Wollgarten, J. Haug, J. Banhart, Acta Mater. 53 (2005) 3861-3870.

[5] M.C. Gao, G.J. Shiflet, Scr. Mater. 53 (2005) 1129-1134. 
[6] J.C. Foley, D.R. Allen, J.H. Perepezko, Scr. Mater. 35(5) (1996) 655-660.

[7] Q. Li, E. Johnson, A. Johansen, L. SarholdKristensen, J. Mater. Res. 7 (1992) 2756-2764.

[8] L. Battezzati, M. Kusy', P. Rizzi, V. Ronto', J. Mater. Sci. 39 (2004) 3927-3934.

[9] Y. Zhang, P.J. Warren, A. Cerezo, Mater. Sci. Eng. A 327 (2002) 109-115.

[10] H.W. Yang, S.C. Tjong, J.Q. Wang, Mater. Sci. Eng. A 406 (2005) 160-165.

[11] T. Mika, M. Karolus, G. Haneczok, L. Bednarska, E. Łagiewka, B. Kotur, J. NonCryst. Solids 354 (2008) 3099-3106.

[12] J. Rodriguez-Carvajal, Program FullProf, Lab. Léon Brillouin, 1998.
[13] W. Kraus, G. Nolge, PowderCell, Federal Institute for Materials Research and Testing, 1999.

[14] G.K. Williamson, W.H. Hall, Acta Metall. 1 (1953) 22-31.

[15] H.E. Kissinger, Anal. Chem. 29 (1957) 1702-1705.

[16] K. Hono, Y. Zhang, A.P. Tsai, A. Inoue, T. Sakura, Scr. Metall. Mater. 32(2) (1995) 191-196.

[17] R.E. Gladyshevskii, K. Cenzual, E. Parthé, J. Solid State Chem. 100 (1992) 9-15.

[18] T. Mika, B. Kotur, Chem. Met. Alloys 3 (2010) 208-219. 